\title{
Special Issue: African Canadians, Gender, and SeXuality
}

\section{ÉDITION SPÉCIALE: LES AFRO-CANADIENS, LE GENRE ET LA SEXUALITÉ}

JoHANNE JEAN-PIERRE

LANCE MCCREADY

Abstract. This is the introduction to a special issue, focusing on African Canadians, gender and sexuality. This special issue adds to the body of empirical knowledge about gender and sexuality and how they relate to identities, structures, and systems within African Canadian communities. All of the articles feature qualitative inquiries. These were conducted in Nova Scotia, Quebec, Ontario, and British Columbia and focused on education, policing, sexual agency and romantic relationships.

Keywords: Black; African Canadians; Race; Gender; Sexuality; Intersectionality 


\section{Aims And Scope}

This special issue adds to the body of empirical knowledge about gender and sexuality and how they relate to identities, structures, and systems within African Canadian communities. African Canadians, also called Black Canadians, are a visible minority group in Canada, and include multigenerational Black Canadians such as African Nova Scotians as well as immigrant communities. Before 1981, most Black immigrants came from Caribbean countries, but there has since been a shift in terms of countries of origin: as of 2016 Black newcomers came primarily from African countries (Statistics Canada 2019). In 2016, 3.5\% of the Canadian population identified as Black Canadian, nearly half of whom lived in Ontario (Statistics Canada 2019). The African Canadian population is younger than the general population in Canada, with a median age of 29.6 years compared to the general population median age of 40.7 years, and more than a quarter of African Canadians are aged 15 or younger (Statistics Canada 2019). At the national level, there are slightly more Black women than Black men, similar to the general population. Almost all Black Canadians reside in census metropolitan areas (94.3\%), especially Toronto, followed by Montreal, Ottawa-Gatineau, Oshawa, Edmonton, Calgary, and Halifax (Statistics Canada 2019). The articles in this special issue expand on what we can learn from census data, and incorporate elements from various disciplines including sociology, criminology, education, geography, and health.

The findings presented in this special issue are timely, given that the United Nations proclaimed 2015-2024 as the International Decade for People of African Descent, with the goal of highlighting the accomplishments of people of African descent, as well as human rights issues affecting this population around the world (United Nations General Assembly 2013). The United Nations Report of Working People of Experts on People of African Descent in Canada (2017) recommended that policymakers examine gender discrimination and intersecting forms of inequalities. Social inequality, including gender inequality, has been a longstanding area of inquiry in the field of sociology. However, although people of African descent have been in Canada since the $17^{\text {th }}$ century, few social science studies have focused on gender and sexuality among African Canadians as they relate to identities, structures, and/or systems. In 2004, Canadian Woman Studies published a special issue titled Women and the Black Diaspora, which had a particular focus on Black Canadian women. In 2008, the Journal of Black Studies published a special issue titled Blacks in Canada: Retrospects, Introspects, Prospects, which explored the erasure and invisibility of people of African 
descent in Canadian historical narratives. In 2012, a special issue of the Southern Journal of Canadian Studies titled Constructing Black Canada invited scholars, community activists, and artists to discuss community engagement and activism.

We hope to build upon the above edited journal issues with articles derived from empirical studies. While there is a rich tradition of historical, theoretical, diasporic, literary and cultural studies engagement within Black Canadian academic literature, we initiated this special issue because we strongly believe that more social scientific empirical knowledge regarding gender and sexuality can enrich future policy decision-making processes and provide much-needed material for instructors and students. Additionally, the Canadian Journal of Sociology/Cahiers Canadiens de Sociologie (CJS/CCS) has never featured a series of articles focused on gender and sexuality within African Canadian communities, so this special issue represents a pioneering effort to advance empirical social science research on gender and sexuality within African Canadian communities.

\section{Summary of Articles}

All of the articles in this special issue feature qualitative inquiries. These were conducted in Nova Scotia, Quebec, Ontario, and British Columbia and focused on education, policing, sexual agency and romantic relationships. There may be systemic reasons why all of the submissions for this special issue are based on qualitative research. Statistics Canada and other government agencies provide limited access to data due to privacy protection concerns; provinces have little incentive to collect comparable data, and when it comes to race, gender and socio-economic status, several government agencies tend to organize data in silos (Andrew-Gee and Grant 2019). Limited access to race-based data from different agencies and institutions may limit quantitative research involving African Canadians (Millar and Owusu-Bempah 2011; Ontario Human Rights Commission 2018; United Nations General Assembly 2017). These and other issues related to quantitative analyses of intragroup dynamics of gender and sexuality among African Canadians should be considered, but an extended discussion of these problems is beyond the scope of this special issue.

Despite their relatively small scales, the featured qualitative studies provide critical insights into how race, gender, and sexuality are related to daily life experiences, meaning-making processes, agency, experiences of discrimination, and individual and collective strategies 
to overcome institutional barriers. Articles explore how negative discourses and stereotypes about Black people affect the gender identities of African Canadians, including Black femininities and masculinities. They also explore how anti-Black racism affects education, health, and wellbeing among African Canadians in their everyday lives. Most authors chose to incorporate critical race theory or critical race feminism as part of their conceptual framework, illustrating how critical race theory, critical race feminism, and intersectionality are increasingly being used as key concepts to understand African Canadians' social experiences. Each article is summarized below.

Jessica Bundy uses critical race theory to interpret semi-structured in-depth interviews conducted with three Black women between 2015 and 2016 in Nova Scotia. Interviews focused on their experiences of policing in their community, and Bundy examines how race and gender shape how African Nova Scotian mothers experience the police in a rural community with a history of publicized incidents of police brutality. Her findings illustrate how conceptions of mothering and social activism among African Nova Scotian women shape their direct and vicarious experiences of policing. The article raises important questions about gender relations in Black communities, and particularly how Black women experience the criminal justice system in rural areas that are historically Black.

Gina Lafortune uses intersectionality theory to interpret semi-structured interviews with 53 students and personnel in Montreal CEGEPS during the 2017-2018 academic year. Interviews explored postsecondary experiences, specifically how ethnicity, social class, migration status, and gender affect the educational trajectories among students of Haitian origin. The findings indicate that financial stress, migration status, and Black minority status can all exacerbate the challenges of the transition from high school to CEGEP. Moreover, the educational trajectories of students differed by gender. Young men of Haitian origin, in particular, were perceived as less engaged and in great need of career guidance, and were more likely than their female counterparts to drop out after their first semester. Some staff members attributed these gender differences to cultural factors, while other staff members and students pointed to gendered socialization practices within the family. Several young male interviewees referred to structural barriers associated with negative perceptions of Black males within postsecondary institutions. This article illustrates the importance of exploring how and why race and gender differentiate educational trajectories in African Canadian communities. 
Carl James uses critical race theory and positioning theory to examine how Black boys in the Greater Toronto Area envision their transition to high school. Based on analysis of one focus group with nine participants, James explores career aspirations among Black male students in middle school, as well as how they feel others perceive Black boys, and how they resist stereotypes. The findings offer rich insights into a range of schooling experiences, particularly teacher-student interactions and how these influence the ways Black male students conceptualize their academic identities. They also point to institutional processes and mechanisms that prevent Black male students from fulfilling their goals and professional aspirations. The article makes important contributions to the scholarly literature on the schooling experiences of African Canadian students, and raises the question of how different contexts can influence self-conceptions and perspectives among Black boys.

Husbands et al. use critical race theory and masculinities theory to interpret focus groups and interviews with 69 heterosexual Black male participants in Toronto. The authors challenge contemporary stereotypes about Black men's hypersexuality by featuring narratives of heterosexual Black men that document complex experiences of sexuality and sexual agency, including how systemic and structural conditions affect their overall wellbeing. The article reveals possibilities for emergent Black masculinities and provides insights into new ways of approaching HIV prevention and health promotion. The authors conclude that stereotypes about heterosexual Black men are reinforced in the absence of more critical analyses of their narratives, which reveal a range of masculine identities and social determinants of health.

Finally, Gillian Creese uses intersectionality and critical race feminism to analyze transcripts of semi-structured interviews with 35 adult children of immigrants from sub-Saharan Africa living in the Greater Vancouver area. Her article illustrates how gendered and sexualized discourses of Blackness shape everyday and romantic experiences. She explores how Black young adults living in Vancouver negotiate hypervisibility and scrutiny, and how generalized and gender-specific negative stereotypes of Black people affect their wellbeing. Her article also explores how race and gender constructs affect romantic relationships and gender relations. As with the preceding articles, her findings point to how processes related to gender and racialization affect everyday life, and demonstrate how intersectional analyses can enrich our understanding of romantic relationships and couple formation. 


\section{Research with, For, and by African Canadians}

Scholars from various disciplines in the humanities and the social sciences engage in research with African Canadian communities, but more sociology-specific scholarship is needed to address one of the goals of the International Decade for People of African Descent - to highlight human rights issues. More sociological research is also needed to investigate African Canadian gender relations in terms of employment, health, and mental health; this research could take a national or multilingual scope. There is also a need for more research focusing on the experiences, health, and education outcomes of specific ethnocultural, religious, or citizenship status (e.g., refugee, asylum seeking, liminal) groups of African descent. All of these investigations would benefit from taking an intersectional approach to explore how multiple social identities and forms of discrimination affect meaning-making and outcomes. Studies that draw solely from only one body of literature (e.g., immigration, official language minorities, or racial and ethnic studies) may miss opportunities to make meaningful connections with previous findings from other fields that relate to African Canadians.

When conducting research involving African Canadian communities, sociologists should strive to employ an ethical and critical approach that centres the agency and voices of African Canadians. This requires meaningful input from African Canadian scholars and community members before, during, and after the research, including knowledge mobilization activities. This will require developing new frameworks for relationshipbuilding and reciprocity throughout the research process. The articles included in this special issue highlight the importance of including the views and priorities of Black community members, including those who may be less familiar with the assumptions and intentions of researchers. We encourage sociological research with African Canadian scholars and community members as principal and co-investigators; this kind of community-based approach is more likely to produce findings that are relevant for African Canadian communities. This will require the critical step of involving and mentoring Black senior undergraduate and graduate students on various sociological research projects, with the goal of building capacity and developing more research with, for, and by African Canadian sociologists and communities.

We hope that this special issue will spark conversations about race, gender, and sexuality as they relate to identities, structures, and systems within African Canadian communities, and also that it will facilitate the inclusion of course material that pertains specifically to African Canadians. We chose to publish this special issue in an open-access peer-re- 
viewed journal to make it easier for community members to retrieve and read the articles. We hope that sociology departments will highlight local events related to the International Decade for People of African Descent, and that they will address social problems related to race, gender equity, and the effects of anti-Black racism.

\section{ACKNowledgements}

The publication of this special issue has been supported by a Ryerson University Faculty of Community Services Publication Grant and research funding from the University of Toronto. We would like to thank all the scholars who served as blind peer reviewers. Your collegial contributions made this special issue possible.

\section{REFERENCES}

Andrew-Gee, E. and Grant, T. (2019, January 26). In the dark: The cost of Canada's data deficit, Toronto, ON: Globe and Mail. Retrieved from: https:// www.theglobeandmail.com/canada/article-in-the-dark-the-cost-of-canadas-data-deficit/

Millar, Paul, and Akwasi Owusu-Bempah. 2011. Whitewashing criminal justice in Canada: Preventing research through data suppression. Canadian Journal of Law and Society 26(3): 653-661.

Ontario Human Rights Commission. 2018. Interrupted Childhoods: Over-representation of Indigenous and Black Children in Ontario Child Welfare. Toronto: Queen's Printer for Ontario. Retrieved from : http://www.ohrc. on.ca/en/news_centre/ohrc-releases-report-its-inquiry-over-representation-indigenous-and-black-children-ontario $\% \mathrm{E} 2 \% 80 \% 99$ s-child

Statistics Canada. 2019. Diversity of the Black Population in Canada: An Overview - Catalogue no. 89-657-X2019002. Ottawa: Statistics Canada.

United Nations General Assembly. 2013. Proclamation of the International Decade for People of African Descent: Resolution Adopted by the General Assembly on 23 December 2013. Human Rights Council. Retrieved from https://undocs.org/A/RES/68/237

United Nations General Assembly. 2017. Report of the Working Group of Experts on People of African Descent on its Mission to Canada. Human Rights Council. Retrieved from https://ansa.novascotia.ca/sites/default/ files/files/report-of-the-working-group-of-experts-on-people-of-africandescent-on-its-mission-to-canada.pdf 
Johanne Jean-Pierre, $\mathrm{PhD}$, is an Assistant Professor in the School of Child and Youth Care at Ryerson University. She holds a $\mathrm{PhD}$ in sociology from McMaster University and conducts bilingual research projects in the fields of sociology of education and child and youth studies. Her current research program explores postsecondary trajectories and experiences, promising non-punitive school discipline practices, and child and youth care pedagogy. Her research focuses on best policies and practices for working with refugee and immigrant youth, African Canadian communities, and official language minorities, particularly Francophone minority communities.

Email: jjeanpierre@ryerson.ca

Lance T. McCready, $\mathrm{PhD}$, is an Associate Professor in the Department of Leadership, Higher and Adult Education, and Director of the Transitional Year Program, at the University of Toronto. His research program is broadly concerned with the sociology of Black children, youth and families. He has served as Principal Investigator on projects focusing on the educational trajectories of Black queer youth, restorative practices for Black families involved in the child welfare system, and migration and sexual health among newcomer young Black men who have sex with men. He is the author of Making Space for Diverse Masculinities, published by Peter Lang. He earned his MA and $\mathrm{PhD}$ in Social and Cultural Studies in Education from the University of California, Berkeley, with Designated Emphasis in Women, Gender and Sexuality Studies.

Email: lance.mccready@utoronto.ca 